\title{
Estimation of Sexual Dimorphism of the Mandible in Coastal Karnataka and Kerala Populations using Cone Beam Computed Tomography
}

\author{
Kumuda Rao ${ }^{10} \quad$ Mahabalesh Shetty ${ }^{20} \quad$ U. S. Krishna Nayak ${ }^{30}$ G. Subhas Babu1(i) \\ D. Prashanth Shetty ${ }^{4}$ Prajwal K. Shetty ${ }^{5}$
}

1 Department of Oral Medicine and Radiology, AB Shetty Memorial

Address for correspondence Mahabalesh Shetty, MD, Department of Institute of Dental Sciences, Nitte (Deemed to be University),

Deralakatte, Mangalore, Karnataka, India

2 Department of Forensic Medicine and Toxicology, KS Hegde Medical Academy, Nitte (Deemed to be University), Deralakatte, Mangalore, Karnataka, India

${ }^{3}$ AB Shetty Memorial Institute of Dental Sciences, Nitte (Deemed to Forensic Medicine and Toxicology, KS Hegde Medical Academy, Nitte (Deemed to be University), Deralakatte, Mangalore 575018, Karnataka, India (e-mail: drmabs@yahoo.co.in).

be University), Deralakatte, Mangalore, Karnataka, India

${ }^{4}$ Department of Reproductive and Molecular Biology, KS Hegde Medical Academy, Nitte (Deemed to be University), University, Deralakatte, Mangalore, Karnataka, India

${ }^{5}$ Department of Orthodontics and Dentofacial Orthopedics, AB Shetty Memorial Institute of Dental Sciences, Nitte (Deemed to be University), Deralakatte, Mangalore, Karnataka, India

J Health Allied Sci ${ }^{\mathrm{NU}}$ 2022;12:106-112.

Abstract

Keywords
- sexual dimorphism
- forensic facial
reconstruction
- morphometric
measurements
- cone beam computed
tomography
- mandible

Objective The mandible has been used for sex determination and forensic identification due to its unique anatomy and morphology. Every part of the mandible is unique, including the shape and size of the temperomandibular joint, the ramus, the body and the symphysis region, and the inferior alveolar canal. In addition, the position and placement of the teeth within their sockets are unique for every individual.

Sample Population A study was conducted on 20 males and females to estimate sexual dimorphism using anthropometric measurements obtained by cone beam computed tomography images of the mandible of Karnataka and Kerala populations. Materials and Methods The mean, standard deviation, and standard error along with the confidence interval of different measurements were documented. Various measurements between the sexes were compared using Student's $t$-test. Association between categorical variables was analyzed using the Chi-square test. A p-value $<0.05$ was considered to be statistically significant. Data were analyzed using statistical SPSS software. Results The $p$-value of $\mathrm{mRBr} L, G A L$, and GA R among females was significantly higher in the Karnataka population when compared with that in the Kerala population. The Karnataka State population showed significantly higher values of $R L R, B i G B r$, and $B i C B r$ among males, and the $p$-value of the Kerala population for GGL $L$ and GGL $R$ was significant and higher among the males.

Conclusion The data derived from the above study suggest that the mandibular anthropometric measurements used may be applied for forensic sex estimation.
DOI https://doi.org/ $10.1055 / \mathrm{s}-0041-1736270$ ISSN 2582-4287.

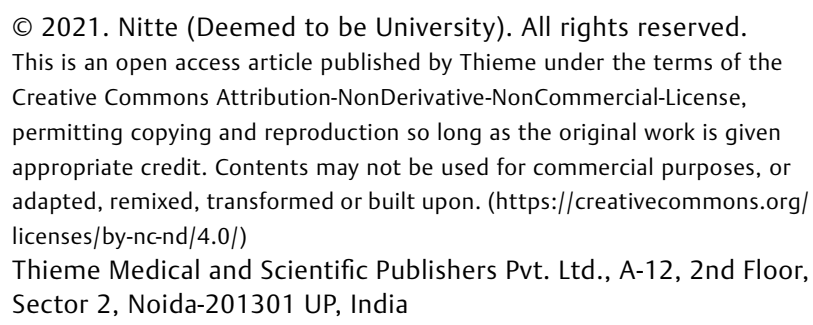




\section{Introduction}

Sexual dimorphism describes morphologic differences between the sexes, although it also describes any biological process that differs between men and women. ${ }^{1}$ Sex determination or estimation is important for human identification for judicial or social reasons. This study attempts to establish possible morphological parameters for the same using cone beam computed tomography ( $\mathrm{CBCT}$ ) images of the human mandible. The advent of CBCT has simplified the process of three-dimensional (3D) imaging and assessment of the face. As anthropological data are specific to race/ethnicity/population, our study was attempted to estimate the morphological measurements of the mandible for the purpose of sexual dimorphism in Coastal Karnataka and Kerala populations.

\section{Materials and Methods}

This retrospective study was performed using mandibular CBCT data of 20 patients visiting the Department of Oral Medicine and Radiology from our institution as per the inclusion and exclusion criteria of the study. As a part of the study, approval was obtained from the Institutional Ethics Committee. The inclusion criteria comprised the CBCT of subjects who visited our institution from coastal Karnataka and north Kerala and aged between 18 to 30 years. Patients with congenital anomalies/syndromes, orofacial pathologies, orthodontic corrections, history of trauma, surgical intervention, and exposure to radiotherapy were excluded from the study. СВCT data of 20 subjects, 7 male subjects out of which 3 were from coastal Karnataka and 4 from Kerala, and 13 female subjects, out of which 8 were from coastal Karnataka and 5 from Kerala, were collected using ProMax 3D Mid (Planmeca, Helsinki, Finland). The standard protocol used was a full field of view $200 \times 170 \mathrm{~cm}$; voxel size $400 \mathrm{~mm}$; and exposure time 4.7 seconds. Morphometric measurements were made and analyzed using NEMOCEPH 3D-the exclusive cephalometric and orthodontic software of NemoStudio, The Digital Medical Company. To minimize intra-observer variability, the measurements were marked thrice in a week by two separate observers and the mean values were taken into consideration. The average measurements were analyzed statistically.

The anthropometric measurements were made on reconstructed images generated by the NEMOCEPH software tools. The 3D locations of gonion, condylion, and gnathion ( - Table 1 ) were marked bilaterally on the mandible. The six measurements were measured on the lower jaw as reported by
Kharoshah et al. ${ }^{2}$ and Gamba et al. ${ }^{3}$ which were the gonial angle (GA), ramus length (RL), minimum ramus breadth $(\mathrm{mRBr})$, gonion-gnathion length (GGL), bicondylar breadth ( $\mathrm{BiCBr})$, and bigonial breadth (BiGBr). The 3D sagittal sections were used for first four measurements and 3D axial sections were used for the last two measurements.

\section{Statistical Analysis}

The mean, standard deviation, and standard error along with the confidence interval of different measurements were documented. Various measurements were compared between the sexes using Student's $t$-test. Association between categorical variables was analyzed using the Chi-square test. A $p$-value $<0.05$ was considered to be statistically significant. Data were analyzed using statistical SPSS software.

\section{Results}

This study presents morphometric measurements of 20 mandibles of patients from Karnataka and Kerala obtained by analyzing their $\mathrm{CBCT}$ images.

\section{Descriptive Statistics}

The data submitted for statistical analysis for this study consisted of 7 male subjects, out of which 3 were from state 1 and 4 from state 2; 13 female subjects, out of which, 8 were from state 1 and 5 from state 2 (- Tables 2-4). Males showed higher mean morphometric measurements concerning all metric parameters when compared with females. The females revealed a higher degree of mean left and right gonial angle measurements than males ( - Table 2 ).

The statistical analysis revealed that among the males, no significant difference was seen in the study parameters between the two states ( - Table 3 ). However, among the females, $\mathrm{mRBr} L, G A \mathrm{~L}$, and GA R were significantly higher in the Karnataka population as compared with those in Kerala population, which were $0.02,0.03$, and 0.003 respectively (-Table 4). In the Karnataka population RL R, BiGBr, and $\mathrm{BiCBr}$ were significantly higher among males when completed to those in females, which were $0.009,0.004$, and 0.04 respectively (-Table 5 ), whereas the $p$-value of Kerala population for GGL L and GGL R were both 0.01 ; hence, it was significant and higher among males than females (-Table 6). There was no significant difference in other study parameters between the two sexes or states.

Table 1 Skeletal landmarks

\begin{tabular}{|l|l|l|}
\hline Sl. No. & $\begin{array}{l}\text { Skeletal landmark } \\
\text { name (ABBR) }\end{array}$ & Definition \\
\hline 1. & Gonion (go) & $\begin{array}{l}\text { Point on the rounded margin of the angle of the mandible, bisecting two lines, one } \\
\text { following the vertical margin of the ramus and the other following the horizontal margin of } \\
\text { the corpus of mandible, which forms the most inferior, posterior, and lateral points on the } \\
\text { external angle of the mandible }\end{array}$ \\
\hline 2. & Gnathion (gn) & The most inferior and anterior points on the profile curvature of the chin \\
\hline 3. & Condylion (cn) & The most superior and posterior points of the mandibular condyle \\
\hline
\end{tabular}


Table 2 Descriptive statistics: frontal

\begin{tabular}{|c|c|c|c|c|c|c|c|c|c|}
\hline & \multicolumn{3}{|c|}{ Sex 1} & \multicolumn{3}{|c|}{ Sex 2} & \multirow[t]{2}{*}{ Wilks' Lambda } & \multirow[t]{2}{*}{$F$} & \multirow[t]{2}{*}{$p$-Value } \\
\hline & $N$ & Mean & SD & $N$ & Mean & SD & & & \\
\hline RL L & 7 & 45.17 & 6.93 & 13 & 40.34 & 6.34 & 0.88 & 2.48 & 0.13 (NS) \\
\hline RL R & 7 & 48.42 & 5.64 & 13 & 42.70 & 5.98 & 0.81 & 4.32 & 0.05 (NS) \\
\hline GGL L & 7 & 78.11 & 6.81 & 13 & 71.10 & 4.01 & 0.68 & 8.56 & $0.009^{*}$ \\
\hline GGL R & 7 & 77.08 & 5.27 & 13 & 70.45 & 3.26 & 0.60 & 12.24 & $0.003^{*}$ \\
\hline $\mathrm{mRBr} \mathrm{L}$ & 7 & 30.69 & 3.01 & 13 & 28.76 & 2.62 & 0.89 & 2.23 & 0.15 (NS) \\
\hline $\mathrm{mRBr} R$ & 7 & 30.45 & 2.46 & 13 & 28.34 & 2.90 & 0.87 & 2.66 & 0.12 (NS) \\
\hline$\overline{G A L}$ & 7 & 120.99 & 3.65 & 13 & 121.05 & 4.50 & 1.00 & 0.00 & 0.98 (NS) \\
\hline GA R & 7 & 120.74 & 3.12 & 13 & 121.53 & 4.09 & 0.99 & 0.20 & 0.66 (NS) \\
\hline $\mathrm{BiGBr}$ & 7 & 92.81 & 4.48 & 13 & 84.41 & 4.84 & 0.56 & 14.42 & $0.001^{*}$ \\
\hline $\mathrm{BiCBr}$ & 7 & 115.85 & 7.94 & 13 & 109.59 & 6.12 & 0.82 & 3.87 & 0.07 (NS) \\
\hline
\end{tabular}

Abbreviation: NS, non-significant. ${ }^{*} p<0.05$, statistically significant.

Table 3 Comparison of parameters between the states among males

\begin{tabular}{|c|c|c|c|c|c|c|c|c|c|c|}
\hline & \multirow[t]{2}{*}{ State } & \multirow[t]{2}{*}{$N$} & \multirow[t]{2}{*}{ Mean } & \multirow[t]{2}{*}{ SD } & \multirow[t]{2}{*}{ Mean difference } & \multicolumn{2}{|c|}{$\begin{array}{l}95 \% \mathrm{Cl} \text { of the } \\
\text { difference }\end{array}$} & \multirow[t]{2}{*}{$t$} & \multirow[t]{2}{*}{$\mathrm{df}$} & \multirow[t]{2}{*}{$p$-Value } \\
\hline & & & & & & Lower & Upper & & & \\
\hline \multirow[t]{2}{*}{ RL L } & 1 & 3 & 48.29 & 7.24 & \multirow[t]{2}{*}{5.45} & \multirow[t]{2}{*}{-8.06} & \multirow[t]{2}{*}{18.96} & \multirow[t]{2}{*}{1.04} & \multirow[t]{2}{*}{5} & \multirow[t]{2}{*}{0.35 (NS) } \\
\hline & 2 & 4 & 42.83 & 6.63 & & & & & & \\
\hline \multirow[t]{2}{*}{ RL R } & 1 & 3 & 52.46 & 1.99 & \multirow[t]{2}{*}{7.08} & \multirow[t]{2}{*}{-1.93} & \multirow[t]{2}{*}{16.08} & \multirow[t]{2}{*}{2.02} & \multirow[t]{2}{*}{5} & \multirow[t]{2}{*}{0.10 (NS) } \\
\hline & 2 & 4 & 45.39 & 5.69 & & & & & & \\
\hline \multirow[t]{2}{*}{ GGL L } & 1 & 3 & 74.62 & 8.25 & \multirow[t]{2}{*}{-6.11} & \multirow[t]{2}{*}{-18.97} & \multirow[t]{2}{*}{6.75} & \multirow[t]{2}{*}{-1.22} & \multirow[t]{2}{*}{5} & \multirow[t]{2}{*}{0.28 (NS) } \\
\hline & 2 & 4 & 80.73 & 5.11 & & & & & & \\
\hline \multirow[t]{2}{*}{ GGL R } & 1 & 3 & 74.33 & 5.58 & \multirow[t]{2}{*}{-4.82} & \multirow[t]{2}{*}{-14.71} & 5.08 & -1.25 & 5 & 0.27 (NS) \\
\hline & 2 & 4 & 79.15 & 4.64 & & & & & & \\
\hline $\mathrm{mRBr} \mathrm{L}$ & 1 & 3 & 32.29 & 2.49 & 2.79 & -2.84 & 8.41 & 1.27 & 5 & 0.26 (NS) \\
\hline & 2 & 4 & 29.50 & 3.09 & & & & & & \\
\hline $\mathrm{mRBr} R$ & 1 & 3 & 31.35 & 2.16 & 1.58 & -3.39 & 6.56 & 0.82 & 5 & 0.45 (NS) \\
\hline & 2 & 4 & 29.77 & 2.76 & & & & & & \\
\hline GA L & 1 & 3 & 121.34 & 5.61 & 0.61 & -7.21 & 8.43 & 0.20 & 5 & 0.85 (NS) \\
\hline & 2 & 4 & 120.73 & 2.35 & & & & & & \\
\hline GA R & 1 & 3 & 121.16 & 4.90 & 0.73 & -5.93 & 7.40 & 0.28 & 5 & 0.79 (NS) \\
\hline & 2 & 4 & 120.42 & 1.79 & & & & & & \\
\hline $\mathrm{BiGBr}$ & 1 & 3 & 94.84 & 1.83 & 3.55 & -5.18 & 12.27 & 1.05 & 5 & 0.34 (NS) \\
\hline & 2 & 4 & 91.30 & 5.54 & & & & & & \\
\hline $\mathrm{BiCBr}$ & 1 & 3 & 118.07 & 7.95 & 3.89 & -12.60 & 20.38 & 0.61 & 5 & 0.57 (NS) \\
\hline & 2 & 4 & 114.18 & 8.68 & & & & & & \\
\hline
\end{tabular}

Abbreviations: $\mathrm{Cl}$, confidence interval; NS, non-significant.

Note: Independent sample $t$-test.

Interpretation: In sex 1 , there is no significant difference in the study parameters between the two states $(p>0.05)$. 
Table 4 Comparison of parameters between the state among females

\begin{tabular}{|c|c|c|c|c|c|c|c|c|c|c|}
\hline & \multirow[t]{2}{*}{ State } & \multirow[t]{2}{*}{$N$} & \multirow[t]{2}{*}{ Mean } & \multirow[t]{2}{*}{ SD } & \multirow[t]{2}{*}{ Mean difference } & \multicolumn{2}{|c|}{$\begin{array}{l}95 \% \mathrm{Cl} \text { of the } \\
\text { difference }\end{array}$} & \multirow[t]{2}{*}{$t$} & \multirow[t]{2}{*}{ df } & \multirow[t]{2}{*}{$p$-Value } \\
\hline & & & & & & Lower & Upper & & & \\
\hline \multirow[t]{2}{*}{ RL L } & 1 & 8 & 39.91 & 4.97 & \multirow[t]{2}{*}{-1.12} & \multirow[t]{2}{*}{-9.39} & \multirow[t]{2}{*}{7.15} & \multirow[t]{2}{*}{-0.30} & \multirow[t]{2}{*}{11} & \multirow[t]{2}{*}{0.77 (NS) } \\
\hline & 2 & 5 & 41.03 & 8.73 & & & & & & \\
\hline \multirow[t]{2}{*}{ RL R } & 1 & 8 & 41.59 & 5.44 & \multirow[t]{2}{*}{-2.89} & \multirow[t]{2}{*}{-10.49} & \multirow[t]{2}{*}{4.71} & \multirow[t]{2}{*}{-0.84} & \multirow[t]{2}{*}{11} & \multirow[t]{2}{*}{0.42 (NS) } \\
\hline & 2 & 5 & 44.48 & 7.00 & & & & & & \\
\hline \multirow[t]{2}{*}{ GGL L } & 1 & 8 & 71.15 & 4.35 & \multirow[t]{2}{*}{0.15} & \multirow[t]{2}{*}{-5.10} & \multirow[t]{2}{*}{5.40} & \multirow[t]{2}{*}{0.06} & \multirow[t]{2}{*}{11} & \multirow[t]{2}{*}{0.95 (NS) } \\
\hline & 2 & 5 & 71.00 & 3.88 & & & & & & \\
\hline \multirow[t]{2}{*}{ GGL R } & 1 & 8 & 70.91 & 3.28 & \multirow[t]{2}{*}{1.19} & \multirow[t]{2}{*}{-3.01} & 5.39 & 0.63 & 11 & 0.55 (NS) \\
\hline & 2 & 5 & 69.72 & 3.45 & & & & & & \\
\hline $\mathrm{mRBr} \mathrm{L}$ & 1 & 8 & 30.01 & 1.97 & 3.23 & 0.55 & 5.92 & 2.65 & 11 & $0.02^{*}$ \\
\hline & 2 & 5 & 26.77 & 2.40 & & & & & & \\
\hline $\mathrm{mRBr} R$ & 1 & 8 & 29.29 & 2.80 & 2.49 & -0.94 & 5.92 & 1.60 & 11 & 0.14 (NS) \\
\hline & 2 & 5 & 26.80 & 2.61 & & & & & & \\
\hline GA L & 1 & 8 & 123.14 & 3.23 & 5.42 & 0.74 & 10.09 & 2.55 & 11 & $0.03^{*}$ \\
\hline & 2 & 5 & 117.72 & 4.46 & & & & & & \\
\hline GA R & 1 & 8 & 123.88 & 2.60 & 6.11 & 2.61 & 9.61 & 3.85 & 11 & $0.003^{*}$ \\
\hline & 2 & 5 & 117.76 & 3.09 & & & & & & \\
\hline $\mathrm{BiGBr}$ & 1 & 8 & 83.78 & 4.72 & -1.64 & -7.89 & 4.61 & -0.58 & 11 & 0.58 (NS) \\
\hline & 2 & 5 & 85.42 & 5.40 & & & & & & \\
\hline $\mathrm{BiCBr}$ & 1 & 8 & 108.25 & 5.40 & -3.49 & -11.16 & 4.19 & -1.00 & 11 & 0.34 (NS) \\
\hline & 2 & 5 & 111.74 & 7.20 & & & & & & \\
\hline
\end{tabular}

Abbreviations: $\mathrm{Cl}$, confidence interval; NS, non-significant.

Note: Independent sample $t$-test.

${ }^{*} p<0.05$, statistically significant.

Interpretation: In sex $2, \mathrm{mRBr} L, G A \mathrm{~L}$, and GA R are significantly higher in state 1 than in state $2(p<0.05)$. There is no significant difference in other study parameters between the two states $(p>0.05)$.

\section{Discussion}

This retrospective study was conducted on mandibular CBCT images of the Karnataka and Kerala population belonging to the age group of 18 to 30 years.

Numerous studies have been conducted on cadavers/fragmentary bones ${ }^{4}$ using two-dimensional imaging modalities, ${ }^{5,6}$ computed tomography (CT), ${ }^{7,8}$ magnetic resonance imaging (MRI), ${ }^{9}$ etc., for the purpose of sexual dimorphism and individual forensic identification. In recent years, studies using CBCT scans of the facial region have contributed immensely to the population metric database toward forensic applications. ${ }^{10-12}$

The osteometric parameters analyzed in our study were gonial angle (GA), ramus length (RL), minimum ramus breadth $(\mathrm{mRBr})$, gonian-gnathion length $(\mathrm{GGL})$, bicondylar length (BiCBr), and bigonial breadth (BiGBr) of the mandible. Osteometric mandibular measurements with the same parameters were first recorded in the Egyptian population by Kharoshah et al using spiral CT scanning. ${ }^{2}$ Our study is unique as there were no systematic investigations or data in the literature that have been recorded with regard to these measurements belonging to this specific population from Karnataka and Kerala. The additional modification in our study is the CBCT imaging modality used due to its advantages over other 3D imaging modalities. ${ }^{13,14}$

The parameters measured in our study were also studied by Gamba et al in the Brazilian population, ${ }^{3}$ where they collected anthropometric measurements using CBCT of mandibular images of 74 males and 85 females. The rate of correct sex estimation was $95.1 \%$ in four variables, enabling the formula to be applied for sex estimation, and accuracy of 93.33\% and $94.74 \%$ was found for estimating males and females, respectively. ${ }^{14}$ The correct predictive accuracy was $83.6 \%$ in males and $84.2 \%$ in females in the study by Kharoshah et al. ${ }^{2}$ The results obtained from our analysis suggest that $95.0 \%$ of the original grouped cases were correctly classified ( - Table $\mathbf{7}$ ).

The purpose of conducting this study is to establish the morphometric measurements in the mandible as parameters of sexual dimorphism. We are further analyzing the same parameters in the said population with a larger sample size 
Table 5 Comparison of parameters between the sexes in coastal Karnataka

\begin{tabular}{|c|c|c|c|c|c|c|c|c|c|c|}
\hline & \multirow[t]{2}{*}{ Sex } & \multirow[t]{2}{*}{$N$} & \multirow[t]{2}{*}{ Mean } & \multirow[t]{2}{*}{ SD } & \multirow[t]{2}{*}{ Mean difference } & \multicolumn{2}{|c|}{$\begin{array}{l}95 \% \mathrm{Cl} \text { of the } \\
\text { difference }\end{array}$} & \multirow[t]{2}{*}{$t$} & \multirow[t]{2}{*}{ df } & \multirow[t]{2}{*}{$p$-Value } \\
\hline & & & & & & Lower & Upper & & & \\
\hline \multirow[t]{2}{*}{ RL L } & 1 & 3 & 48.29 & 7.24 & \multirow[t]{2}{*}{8.38} & \multirow[t]{2}{*}{-0.12} & \multirow[t]{2}{*}{16.88} & \multirow[t]{2}{*}{2.23} & \multirow[t]{2}{*}{9} & \multirow[t]{2}{*}{0.05 (NS) } \\
\hline & 2 & 8 & 39.91 & 4.97 & & & & & & \\
\hline \multirow[t]{2}{*}{ RL R } & 1 & 3 & 52.46 & 1.99 & \multirow[t]{2}{*}{10.88} & \multirow[t]{2}{*}{3.39} & \multirow[t]{2}{*}{18.37} & \multirow[t]{2}{*}{3.29} & \multirow[t]{2}{*}{9} & \multirow[t]{2}{*}{$0.009^{a}$} \\
\hline & 2 & 8 & 41.59 & 5.44 & & & & & & \\
\hline \multirow[t]{2}{*}{ GGL L } & 1 & 3 & 74.62 & 8.25 & \multirow[t]{2}{*}{3.47} & \multirow[t]{2}{*}{-4.90} & \multirow[t]{2}{*}{11.84} & \multirow[t]{2}{*}{0.94} & \multirow[t]{2}{*}{9} & \multirow[t]{2}{*}{0.37 (NS) } \\
\hline & 2 & 8 & 71.15 & 4.35 & & & & & & \\
\hline \multirow[t]{2}{*}{ GGL R } & 1 & 3 & 74.33 & 5.58 & \multirow[t]{2}{*}{3.42} & \multirow[t]{2}{*}{-2.57} & 9.41 & 1.29 & 9 & 0.23 (NS) \\
\hline & 2 & 8 & 70.91 & 3.28 & & & & & & \\
\hline $\mathrm{mRBr} \mathrm{L}$ & 1 & 3 & 32.29 & 2.49 & 2.28 & -0.93 & 5.49 & 1.60 & 9 & 0.14 (NS) \\
\hline & 2 & 8 & 30.01 & 1.97 & & & & & & \\
\hline $\mathrm{mRBr} R$ & 1 & 3 & 31.35 & 2.16 & 2.06 & -2.03 & 6.15 & 1.14 & 9 & 0.28 (NS) \\
\hline & 2 & 8 & 29.29 & 2.80 & & & & & & \\
\hline GA L & 1 & 3 & 121.34 & 5.61 & -1.80 & -7.75 & 4.16 & -0.68 & 9 & 0.51 (NS) \\
\hline & 2 & 8 & 123.14 & 3.23 & & & & & & \\
\hline GA R & 1 & 3 & 121.16 & 4.90 & -2.72 & -7.70 & 2.26 & -1.24 & 9 & 0.25 (NS) \\
\hline & 2 & 8 & 123.88 & 2.60 & & & & & & \\
\hline $\mathrm{BiGBr}$ & 1 & 3 & 94.84 & 1.83 & 11.06 & 4.55 & 17.58 & 3.84 & 9 & $0.004^{a}$ \\
\hline & 2 & 8 & 83.78 & 4.72 & & & & & & \\
\hline $\mathrm{BiCBr}$ & 1 & 3 & 118.07 & 7.95 & 9.82 & 0.54 & 19.10 & 2.39 & 9 & $0.04^{a}$ \\
\hline & 2 & 8 & 108.25 & 5.40 & & & & & & \\
\hline
\end{tabular}

Abbreviations: $\mathrm{Cl}$, confidence interval; NS, non-significant.

Note: Independent sample $t$-test, ${ }^{a} p<0.05$, statistically significant.

Interpretation: In state $1, \mathrm{RL}, \mathrm{RiGBr}$, and $\mathrm{BiCBr}$ are significantly higher in sex 1 than in sex $2(p<0.05)$. There is no significant difference in other study parameters between the two sexes $(p>0.05)$.

Table 6 Comparison of parameters between the sexes in Kerala

\begin{tabular}{|c|c|c|c|c|c|c|c|c|c|c|}
\hline & \multirow[t]{2}{*}{ Sex } & \multirow[t]{2}{*}{$N$} & \multirow[t]{2}{*}{ Mean } & \multirow[t]{2}{*}{ SD } & \multirow[t]{2}{*}{ Mean difference } & \multicolumn{2}{|c|}{$\begin{array}{l}\text { 95\% } \mathrm{Cl} \text { of the } \\
\text { difference }\end{array}$} & \multirow[t]{2}{*}{$t$} & \multirow[t]{2}{*}{$\mathrm{df}$} & \multirow[t]{2}{*}{$p$-Value } \\
\hline & & & & & & Lower & Upper & & & \\
\hline \multirow[t]{2}{*}{ RL L } & 1 & 4 & 42.83 & 6.63 & \multirow[t]{2}{*}{1.80} & \multirow[t]{2}{*}{-10.73} & \multirow[t]{2}{*}{14.34} & \multirow[t]{2}{*}{0.34} & \multirow[t]{2}{*}{7} & \multirow[t]{2}{*}{0.74 (NS) } \\
\hline & 2 & 5 & 41.03 & 8.73 & & & & & & \\
\hline \multirow[t]{2}{*}{ RL R } & 1 & 4 & 45.39 & 5.69 & \multirow[t]{2}{*}{0.91} & \multirow[t]{2}{*}{-9.36} & \multirow[t]{2}{*}{11.18} & \multirow[t]{2}{*}{0.21} & \multirow[t]{2}{*}{7} & \multirow[t]{2}{*}{0.84 (NS) } \\
\hline & 2 & 5 & 44.48 & 7.00 & & & & & & \\
\hline \multirow[t]{2}{*}{ GGL L } & 1 & 4 & 80.73 & 5.11 & \multirow[t]{2}{*}{9.73} & \multirow[t]{2}{*}{2.67} & \multirow[t]{2}{*}{16.79} & \multirow[t]{2}{*}{3.26} & \multirow[t]{2}{*}{7} & \multirow[t]{2}{*}{$0.01^{*}$} \\
\hline & 2 & 5 & 71.00 & 3.88 & & & & & & \\
\hline \multirow[t]{2}{*}{ GGL R } & 1 & 4 & 79.15 & 4.64 & \multirow[t]{2}{*}{9.43} & \multirow[t]{2}{*}{3.07} & \multirow[t]{2}{*}{15.79} & \multirow[t]{2}{*}{3.51} & \multirow[t]{2}{*}{7} & \multirow[t]{2}{*}{$0.01^{*}$} \\
\hline & 2 & 5 & 69.72 & 3.45 & & & & & & \\
\hline $\mathrm{mRBr} \mathrm{L}$ & 1 & 4 & 29.50 & 3.09 & 2.73 & -1.59 & 7.04 & 1.49 & 7 & $0.18(\mathrm{NS})$ \\
\hline & 2 & 5 & 26.77 & 2.40 & & & & & & \\
\hline $\mathrm{mRBr} R$ & 1 & 4 & 29.77 & 2.76 & 2.97 & -1.28 & 7.21 & 1.65 & 7 & 0.14 (NS) \\
\hline & 2 & 5 & 26.80 & 2.61 & & & & & & \\
\hline
\end{tabular}


Table 6 (Continued)

\begin{tabular}{|c|c|c|c|c|c|c|c|c|c|c|}
\hline & \multirow[t]{2}{*}{ Sex } & \multirow[t]{2}{*}{$N$} & \multirow[t]{2}{*}{ Mean } & \multirow[t]{2}{*}{ SD } & \multirow[t]{2}{*}{ Mean difference } & \multicolumn{2}{|c|}{$\begin{array}{l}95 \% \mathrm{Cl} \text { of the } \\
\text { difference }\end{array}$} & \multirow[t]{2}{*}{$t$} & \multirow[t]{2}{*}{ df } & \multirow[t]{2}{*}{$p$-Value } \\
\hline & & & & & & Lower & Upper & & & \\
\hline \multirow[t]{2}{*}{ GA L } & 1 & 4 & 120.73 & 2.35 & \multirow[t]{2}{*}{3.01} & \multirow[t]{2}{*}{-2.87} & \multirow[t]{2}{*}{8.89} & \multirow[t]{2}{*}{1.21} & \multirow[t]{2}{*}{7} & \multirow[t]{2}{*}{0.27 (NS) } \\
\hline & 2 & 5 & 117.72 & 4.46 & & & & & & \\
\hline \multirow[t]{2}{*}{ GA R } & 1 & 4 & 120.42 & 1.79 & \multirow[t]{2}{*}{2.66} & \multirow[t]{2}{*}{-1.49} & \multirow[t]{2}{*}{6.80} & \multirow[t]{2}{*}{1.52} & \multirow[t]{2}{*}{7} & \multirow[t]{2}{*}{0.17 (NS) } \\
\hline & 2 & 5 & 117.76 & 3.09 & & & & & & \\
\hline \multirow[t]{2}{*}{$\mathrm{BiGBr}$} & 1 & 4 & 91.30 & 5.54 & \multirow[t]{2}{*}{5.88} & \multirow[t]{2}{*}{-2.79} & \multirow[t]{2}{*}{14.54} & \multirow[t]{2}{*}{1.60} & \multirow[t]{2}{*}{7} & \multirow[t]{2}{*}{0.15 (NS) } \\
\hline & 2 & 5 & 85.42 & 5.40 & & & & & & \\
\hline \multirow[t]{2}{*}{$\mathrm{BiCBr}$} & 1 & 4 & 114.18 & 8.68 & \multirow[t]{2}{*}{2.44} & \multirow[t]{2}{*}{-10.04} & \multirow[t]{2}{*}{14.92} & \multirow[t]{2}{*}{0.46} & \multirow[t]{2}{*}{7} & \multirow[t]{2}{*}{0.66 (NS) } \\
\hline & 2 & 5 & 111.74 & 7.20 & & & & & & \\
\hline
\end{tabular}

Abbreviations: $\mathrm{Cl}$, confidence interval; NS, non-significant.

Independent sample $t$-test.

${ }^{*} p<0.05$, statistically significant.

Interpretation: In state 2 , GGL L and GGL R are significantly higher in sex 1 than in sex $2(p<0.05)$. There is no significant difference in other study parameters between the two sexes $(p>0.05)$.

Table 7 Classification results

\begin{tabular}{|l|l|l|l|l|}
\hline \multirow{2}{*}{} & \multirow{2}{*}{ Sex } & \multicolumn{2}{|l|}{$\begin{array}{l}\text { Predicted group } \\
\text { membership }\end{array}$} & \multirow{2}{*}{ Total } \\
\cline { 3 - 4 } & & $\mathbf{1}$ & 2 & \\
\hline \multirow{3}{*}{ Count } & 1 & 7 & 0 & 7 \\
\cline { 2 - 5 } & 2 & 1 & 12 & 13 \\
\hline$\%$ & 1 & 100.0 & 0.0 & 100.0 \\
\cline { 2 - 5 } & 2 & 7.7 & 92.3 & 100.0 \\
\hline
\end{tabular}

Note: $95.0 \%$ of the original grouped cases are correctly classified.

for a more definitive conclusion that will aid in the forensic identification of coastal Karnataka and north Kerala populations.

\section{Limitations}

The sample size was small for comparison between the populations. Future research should be aimed at collecting the morphometric data of the craniofacial region using larger population sizes for better confirmatory results and the establishment of a database for specific populations.

\section{Conclusion}

Sex estimation has been a challenge, especially when unknown bony fragments are to be evaluated for individual identification at crime scenes and mass disasters. Segregation of the body fragments to reduce the pool of bodies requiring identification can be made using results obtained from studies pertaining to sexual dimorphism. Our study results imply that there is a definite bright scope for the use of mandibular morphometric measurements in the establishment of sexual dimorphism with the aid of CBCT. This becomes especially true and applicable when there exists a dataset of anthropological measurements pertaining to specific population groups. Hence, research directed toward maintaining a record of anthropological data of targeted population groups has become of utmost importance for forensic applications.

Conflict of Interest

None declared.

\section{Acknowledgment}

The authors would like to thank Dr. Vinayak Kamath, Senior Lecturer, Department of Public Health Dentistry, Government Dental College, Goa, for compiling the statistics.

\section{References}

1 Baker FC, O'Brien LM, Armitage R. Sex differences and menstrualrelated changes in sleep and circadian rhythms. In: Principles and Practice of Sleep Medicine. 5th ed. St Louis: Saunders Elsevier; 2011:1562-1571

2 Kharoshah MAA, Almadani O, Ghaleb SS, Zaki MK, Fattah YAA. Sexual dimorphism of the mandible in a modern Egyptian population. J Forensic Leg Med 2010;17(04):213-215

3 Gamba TDO, Alves MC. Haiter-Neto F. Mandibular sexual dimorphism analysis in CBCT scans of a Brazilian population. J Forensic Radiol Imaging 2014;2(02):104

4 İlgüy D, İlgüy M, Ersan N, Dölekoğlu S, Fişekçioğlu E. Measurements of the foramen magnum and mandible in relation to sex using CBCT. J Forensic Sci 2014;59(03):601-605

5 Divakar DD, John J, Al Kheraif AA, et al. Sex determination using discriminant function analysis in indigenous (Kurubas) children and adolescents of Coorg, Karnataka, India: a lateral cephalometric study. Saudi J Biol Sci 2016;23(06):782-788

6 Patil KR, Mody RN. Determination of sex by discriminant function analysis and stature by regression analysis: a lateral cephalometric study. Forensic Sci Int 2005;147(02-(03):175-180

7 Kallalli BN, Rawson K, Ramaswamy VK, Zakarneh WHA, Singh A, Zingrade J. Sex determination of human mandible using metrical 
parameters by computed tomography: a prospective radiographic short study. J Indian Acad Oral Med Radiol 2016;28(1):7-10

8 Nourbakhsh R, Razi S, Razi T. Evaluation of relation of dimensional measurement of different anatomic skull structures to determine sexual dimorphism in cone beam CT images of an Iranian population. J Res Med Dent Sci 2018;6(03):33-38

9 Rani SU, Rao GV, Kumar DR, Sravya T, Sivaranjani Y, Kumar MP. Age and gender assessment through three-dimensional morphometric analysis of maxillary sinus using magnetic resonance imaging. J Forensic Dent Sci 2017;9(01):46

10 de Oliveira Gamba T, Alves MC, Haiter-Neto F. Analysis of sexual dimorphism by locating the mandibular canal in images of conebeam computed tomography. J Forensic Radiol Imaging 2014; 2:72-76
11 Gamba Tde O, Alves MC, Haiter-Neto F. Mandibular sexual dimorphism analysis in CBCT scans. J Forensic Leg Med 2016; 38:106-110

12 Souto MF, Felippe MB, Gamba TO, Flores IL, de Castro Lopes SLP, Manhães LRC Junior. Cone-beam computed tomography: an accurate diagnostic tool in dental practice for evaluation of anatomic variations in maxillary bone septa. J Neuroinfect Dis 2015;:S1:002

13 Yang F, Jacobs R, Willems G. Dental age estimation through volume matching of teeth imaged by cone-beam CT. Forensic Sci Int 2006;159(01, Suppl Suppl 1):S78-S83

14 Pinsky HM, Dyda S, Pinsky RW, Misch KA, Sarment DP. Accuracy of three-dimensional measurements using cone-beam CT. Dentomaxillofac Radiol 2006;35(06):410-416 